Article

\title{
Environmental-Friendly Contamination Assessment of Habitats Based on the Trace Element Content of Dragonfly Exuviae
}

\author{
Edina Simon ${ }^{1}$, Béla Tóthmérész ${ }^{2, *}$, Olga Kis ${ }^{3}$, Tibor Jakab ${ }^{4}$, Petra Éva Szalay ${ }^{3}$, András Vincze ${ }^{3}$, \\ Edina Baranyai ${ }^{5}$, Sándor Harangi ${ }^{6}$, Margit Miskolczi ${ }^{3}$ and György Dévai ${ }^{3}$ \\ 1 Department of Ecology, University of Debrecen, Egyetem sq. 1, H-4032 Debrecen, Hungary; \\ edina.simon@gmail.com \\ 2 MTA-DE Biodiversity and Ecosystem Services Research Group, Egyetem sq. 1, H-4032 Debrecen, Hungary \\ 3 Department of Hydrobiology, University of Debrecen, Egyetem sq. 1, H-4032 Debrecen, Hungary; \\ kisolgie@gmail.com (O.K.); cajmere86@gmail.com (P.É.S.); vandras@gmail.com (A.V.); \\ miskolczi.margit@science.unideb.hu (M.M.); devai.gyorgy@science.unideb.hu (G.D.) \\ 4 Kossuth Lajos Teacher Training Secondary Grammar and Primary School of Debrecen University, Egyetem \\ sq. 1, H-4032 Debrecen, Hungary; jkbtbr@gmail.com \\ 5 Department of Inorganic and Analytical Chemistry, University of Debrecen, Egyetem sq. 1, H-4032 \\ Debrecen, Hungary; baranyai.edina@science.unideb.hu \\ 6 Novo-Lab Ltd., Kossuth Lajos Street 116, H-1196 Budapest, Hungary; harangis87@gmail.com \\ * Correspondence: tothmerb@gmail.com; Tel.: +36-52-512-700
}

Received: 8 August 2019; Accepted: 17 October 2019; Published: 23 October 2019

\begin{abstract}
We tested the usefulness of exuviae as an environmentally friendly method for exploring the variability of the trace element contents of protected insect populations without killing specimens. It is a notable characteristic of dragonflies that they are good ecological indicators for both aquatic and terrestrial habitat quality. Thus, we investigated the trace element accumulation in different stages of dragonflies: larva, exuvia, and adult. Using microwave plasma atomic emission spectrometry (MP-AES), we analysed the concentrations of $\mathrm{Al}, \mathrm{Ba}, \mathrm{Cr}, \mathrm{Cu}, \mathrm{Fe}, \mathrm{Mn}, \mathrm{Pb}, \mathrm{Sr}$ and $\mathrm{Zn}$. We found that the trace element contents of exuviae are a good proxy of the trace element contents of both the larvae and the adults. We conclude that exuvia is useful for assessing the environmental health of aquatic ecosystems. It is an environmentally friendly method and it can be used even in the case of protected dragonfly species.
\end{abstract}

Keywords: larvae; adults; pollution; exuviae; non-invasive tissue analysis

\section{Introduction}

Among contaminants, some trace elements in the aquatic environment have attracted attention globally because of their toxicity and persistence [1]. Trace elements reside in aquatic and terrestrial systems, and these elements accumulate in plants and animals. They also enter humans through the food chain [2]. For an environmentally friendly assessment of contamination, tissues such as blood plasma of fish [3], frog skin by biopsy [4], lizard single gonadectomy [5], bird fece [6] and feather [7] may be useful. Among invertebrates, the aquatic insects are key biotransporters of contaminants between aquatic and terrestrial ecosystems [8,9].

A species with a complex life cycle may occupy two ecological niches; thus, the study of energy and nutrient flow is complex when using these species [10-12]. Dragonflies have three developmental stages: larva, exuvia and adult [13]. Dragonflies are good ecological indicators for wetland and river quality, because they reflect the quality of both aquatic and terrestrial systems [14-18]. They spend 
their larvae stage in aquatic habitats and use a wide range of terrestrial habitats as adults, and they are important predators in aquatic and terrestrial ecosystems [19-22].

Aquatic insects can accumulate elements such as $\mathrm{Al}, \mathrm{Cd}, \mathrm{Cr}, \mathrm{Cu}, \mathrm{Fe}, \mathrm{Mg}, \mathrm{Mn}$ and $\mathrm{Zn}$ from sediment and from food [23]. In aquatic insects, the concentrations of $\mathrm{Hg}, \mathrm{Cd}, \mathrm{Ni}, \mathrm{Cr}, \mathrm{As}, \mathrm{Pb}, \mathrm{Cu}, \mathrm{Ti}, \mathrm{Zn}$ and Mn change with size, life cycle stages and different bioaccumulation patterns [24]. There are only a few reports dealing with the changes in trace element concentration during different developmental stages [25]. Among these stages, dragonfly adults increase their bioaccumulation potential because they feed on other invertebrates [21]. Larvae and exuviae are also useful to detect accumulation and element bioavailability [24].

Accumulated trace metals can be detoxified and excreted in aquatic invertebrates [26]. Trace elements become associated with the calcium in the exoskeleton matrix. They may be absorbed on the surface of the exoskeleton or bind to the inner exoskeleton matrix after uptake $[27,28]$. During metamorphosis, the protein and lipid content alter; stored resources and decomposing cellular structures are metabolized. Metamorphosis influences metal concentration by metal excretion; thus, the concentration of these metals decreases in the body. Mechanisms of contaminant loss include the exoskeleton as exuvia; the importance of this pathway also depends on the contaminant $[21,29,30]$. The decontamination process under conditions of an intensive intake of trace elements to an organism is the production of excrement [27].

Earlier studies demonstrated that the river clubtail (Gomphus flavipes (Stylurus flavipes)) (Odonata: Gomphidae; Linnaeus, 1758) is a sensitive indicator of pollution [31,32]. This species is a characteristic of large lowland rivers in Europe [33,34] and in Hungary [35]; thus, this species was chosen for our study. The aim of our study was to investigate the trace element accumulation in different stages of the dragonfly to test whether the exuviae may be used as a tool for contamination level assessment. We analysed the trace element concentration of larvae, exuviae and adults of Gomphus flavipes. We hypothesised that the exuvia is useful for the chemical analysis and contamination level assessment of habitats; it may be used even with protected species, because it represents a non-invasive tissue.

\section{Materials and Methods}

\subsection{Sampling Localities}

There were 4 sampling localities along the River Tisza in NE-Hungary: Tuzsér (larvae: $N=19$, exuviae: $\mathrm{N}=39$ and adults: $\mathrm{N}=22$ ), Tiszabercel (larvae: $\mathrm{N}=24$, exuviae: $\mathrm{N}=44$ and adults: $\mathrm{N}=20$ ), Balsa (larvae: $\mathrm{N}=22$, exuviae: $\mathrm{N}=70$ and adults: $\mathrm{N}=18$ ) and Tiszafüred (larvae: $\mathrm{N}=24$, exuviae: $\mathrm{N}=44$ and adults: $\mathrm{N}=24)$. Tuzsér $\left(48^{\circ} 20^{\prime} 40.68^{\prime \prime} \mathrm{N} ; 022^{\circ} 6^{\prime} 16.40^{\prime \prime} \mathrm{E}\right)$ is in the Upper Tisza section; in this section the river meanders, and it is in a near natural state. Tiszabercel $\left(48^{\circ} 9^{\prime} 56.78^{\prime \prime} \mathrm{N}\right.$, $021^{\circ} 40^{\prime} 1.19^{\prime \prime}$ E) and Balsa are in the Middle Tisza section and they are located on the damming reach of the Tiszalök barrage. Balsa $\left(48^{\circ} 10^{\prime} 40.07^{\prime \prime} \mathrm{N}, 21^{\circ} 32^{\prime} 7.07^{\prime \prime} \mathrm{E}\right)$ is downstream of the confluence with the main canal, the Lónyay-fócsatorna, which is contaminated with communal wastewater [36]. Tiszafüred $\left(47^{\circ} 40^{\prime} 15.93^{\prime \prime} \mathrm{N}, 20^{\circ} 48^{\prime} 57.99^{\prime \prime} \mathrm{E}\right)$ is also in the Middle Tisza section in the area of the reservoir Kiskörei-tározó (Tisza-tó); the river flows through the reservoir. Dragonfly larvae were collected from the sandy sediment by using a kick net. Exuviae were hand-picked from the sand surface, stones, branches and plants. Adults were collected by a hand net. Samples were collected in May 2013 and May 2014.

\subsection{Sample Process and Trace Element Analysis}

After collection, the dragonfly samples were washed with water and cleaned with a small brush in the field. Samples were moved to the laboratory where they were transferred individually into polyethylene bags and they were placed in a cooler until sample process. Samples were stored at $-18{ }^{\circ} \mathrm{C}$ until sample processing. Individuals were identified based on [34]. 
Dragonfly samples (larvae, exuviae and adults) were flushed with $250 \mathrm{~mL}$ of double deionised water, and after flushing, each sample was put in a container and was washed individually in an ultrasonic bath with $200 \mathrm{~mL}$ of double deionised water. The cleanliness of samples was checked with a stereomicroscope (Olympus SZX16 stereomicroscope with an SDF objective and a DP 26 digital camera).

The wet body mass of the samples was measured with an analytical balance (Digital Analytical Balance 1702, SARTORIUS GMBH Göttingen) after flushing. After flushing the water, the surface was whipped with a paper towel. After measurement of the wet body mass, samples were dried overnight at $105{ }^{\circ} \mathrm{C}$ (WTB 7200 drying oven, Binder Ltd.) and reweighed to determine their dry mass. The material was digested using $2 \mathrm{~mL}$ of $65 \%(\mathrm{~m} / \mathrm{m})$ nitric acid (Merck) and $0.5 \mathrm{~mL}$ of $30 \%(\mathrm{~m} / \mathrm{m})$ hydrogen peroxide (Merck) in the same container at $80{ }^{\circ} \mathrm{C}$ for $4 \mathrm{~h}$. Digested samples were diluted to $20 \mathrm{~mL}$ using $1 \%(\mathrm{~m} / \mathrm{m})$ nitric acid [37-39].

Trace element analysis in the dragonfly samples was performed by a microwave plasma atomic emission spectrometer (MP-AES 4100, Agilent Technologies). We used six-point calibration procedures with a multi-element calibration solution (Merck ICP multi-element standard solution IV).

\subsection{Statistical Analysis}

We used the SPSS/PC+ statistical software package for the calculations. Canonical discriminant analysis (CDA) was used to evaluate the trace element content of the developmental stages. Homogeneity of variances was tested using the Levene test and the normal distribution was tested with a Shapiro-Wilk test. The trace element contents in the stages (larvae, exuviae and adults) were compared with a Kruskal-Wallis test. In the case of significant differences, Dunn's Multiple Comparison test was used. Pearson rank correlation was used to study the correlation between the trace element contents of larvae, exuviae and adults [40].

\section{Results}

There was clear separation among developmental stages based on the microgramme-scale trace elements per individual of G. flavipes in all the studied areas according to the CDA (Figure 1). The canonical variables were significant $(p<0.001)$ in the different stages (Tables S1-S4, Supplementary Materials).
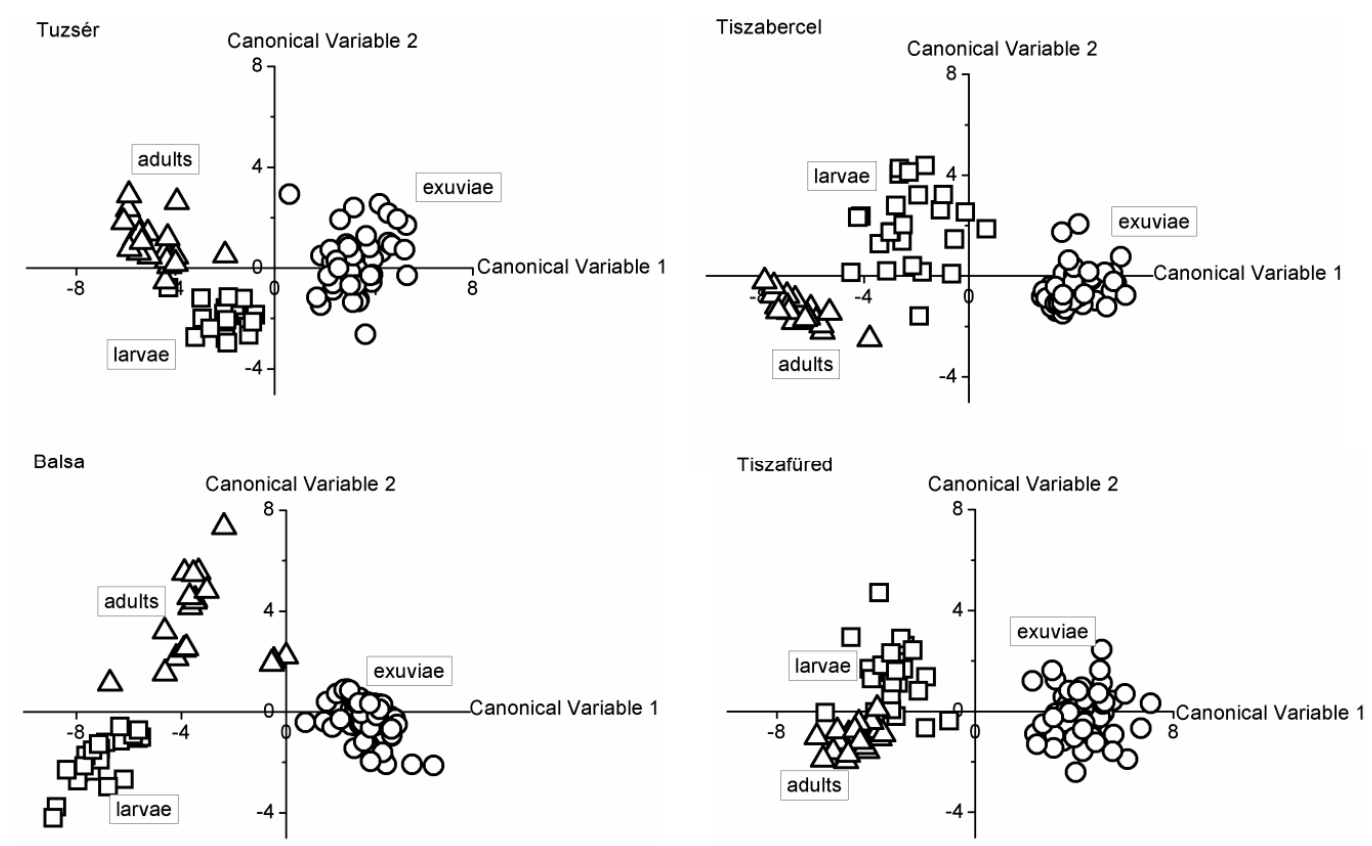

Figure 1. Canonical discriminant plots of trace element contents (microgramme-scale element per individual) in the developmental stages of dragonflies. 
There were significantly higher $\mathrm{Al}, \mathrm{Fe}$, and $\mathrm{Mn}$ contents in exuviae than in the larvae and adult $\mathrm{G}$. flavipes in all the studied areas $(p<0.001)$ (Tables 1-4; and Table S5, Supplementary Materials), except in the case of the Tiszabercel study area. In Tuzsér, a higher Ba content was found in exuviae than in larvae and adults (Table 1).

Table 1. Trace element contents per individual (expressed as mean \pm standard error unit: $\mu \mathrm{g}$ ) of G. flavipes developmental stages in the Tuzsér studied area. Notations: different letters indicate the significant differences at $p<0.05$.

\begin{tabular}{cccc}
\hline \multirow{2}{*}{ Elements } & \multicolumn{3}{c}{ Stages } \\
\cline { 2 - 4 } & Larvae & Exuviae & Adults \\
\hline $\mathrm{Al}$ & $13.4 \pm 1.3^{\mathrm{a}}$ & $87.0 \pm 3.9^{\mathrm{b}}$ & $1.6 \pm 0.2^{\mathrm{c}}$ \\
$\mathrm{Ba}$ & $0.7 \pm 0.1^{\mathrm{a}}$ & $1.9 \pm 0.1^{\mathrm{b}}$ & $0.6 \pm 0.1^{\mathrm{a}}$ \\
$\mathrm{Cr}$ & $0.1 \pm 0.01^{\mathrm{a}}$ & $0.3 \pm 0.01^{\mathrm{b}}$ & $0.1 \pm 0.01^{\mathrm{a}}$ \\
$\mathrm{Cu}$ & $2.2 \pm 0.2^{\mathrm{a}}$ & $1.0 \pm 0.03^{\mathrm{b}}$ & $3.1 \pm 0.2^{\mathrm{a}}$ \\
$\mathrm{Fe}$ & $81.2 \pm 6.4^{\mathrm{a}}$ & $267.1 \pm 11.7^{\mathrm{b}}$ & $10.5 \pm 1.1^{\mathrm{c}}$ \\
$\mathrm{Mn}$ & $13.1 \pm 1.8^{\mathrm{a}}$ & $26.0 \pm 2.0^{\mathrm{b}}$ & $0.4 \pm 0.02^{\mathrm{c}}$ \\
$\mathrm{Pb}$ & $0.1 \pm 0.02^{\mathrm{a}}$ & $0.3 \pm 0.02^{\mathrm{b}}$ & $0.1 \pm 0.01^{\mathrm{a}}$ \\
$\mathrm{Sr}$ & $0.5 \pm 0.03^{\mathrm{a}}$ & $0.7 \pm 0.02^{\mathrm{b}}$ & $0.5 \pm 0.01^{\mathrm{a}}$ \\
$\mathrm{Zn}$ & $12.8 \pm 0.7^{\mathrm{a}}$ & $10.0 \pm 0.7^{\mathrm{b}}$ & $12.2 \pm 0.3^{\mathrm{a}}$ \\
\hline
\end{tabular}

The $\mathrm{Cr}$ content was also higher in exuviae than in larvae and adults in all the studied areas, except in Tiszabercel where the $\mathrm{Cr}$ content was similar between larvae and exuviae, and the $\mathrm{Cr}$ content was below the detection limit in adult individuals (Table 2).

Table 2. Trace element contents per individual (expressed as mean \pm standard error, unit: $\mu \mathrm{g}$ ) of $G$. flavipes developmental stages in the Tiszabercel studied area. Notation: n.d. = not detected, and different letters indicate the significant differences at $p<0.05$.

\begin{tabular}{cccc}
\hline \multirow{2}{*}{ Elements } & \multicolumn{3}{c}{ Stages } \\
\cline { 2 - 4 } & Larvae & Exuviae & Adults \\
\hline $\mathrm{Al}$ & $29.7 \pm 2.4^{\mathrm{a}}$ & $47.2 \pm 2.3^{\mathrm{b}}$ & $0.7 \pm 0.1^{\mathrm{c}}$ \\
$\mathrm{Ba}$ & $0.8 \pm 0.1^{\mathrm{a}}$ & $1.1 \pm 0.1^{\mathrm{a}}$ & $0.1 \pm 0.01^{\mathrm{b}}$ \\
$\mathrm{Cr}$ & $0.04 \pm 0.01^{\mathrm{a}}$ & $0.01 \pm 0,01^{\mathrm{a}}$ & n.d. \\
$\mathrm{Cu}$ & $4.0 \pm 0.2^{\mathrm{a}}$ & $0.8 \pm 0.03^{\mathrm{b}}$ & $3.3 \pm 0.2^{\mathrm{a}}$ \\
$\mathrm{Fe}$ & $95.3 \pm 6.1^{\mathrm{a}}$ & $128.2 \pm 6.4^{\mathrm{b}}$ & $8.0 \pm 0.5^{\mathrm{c}}$ \\
$\mathrm{Mn}$ & $9.1 \pm 1.6^{\mathrm{a}}$ & $10.4 \pm 1.3^{\mathrm{a}}$ & $0.3 \pm 0.01^{\mathrm{c}}$ \\
$\mathrm{Pb}$ & $0.3 \pm 0.03^{\mathrm{a}}$ & $0.2 \pm 0.01^{\mathrm{a}}$ & $0.1 \pm 0.01^{\mathrm{b}}$ \\
$\mathrm{Sr}$ & $0.5 \pm 0.02^{\mathrm{a}}$ & $0.5 \pm 0.01^{\mathrm{a}}$ & $0.5 \pm 0.01^{\mathrm{a}}$ \\
$\mathrm{Zn}$ & $17.0 \pm 0.7^{\mathrm{a}}$ & $9.4 \pm 0.6^{\mathrm{b}}$ & $12.7 \pm 0.2^{\mathrm{c}}$ \\
\hline
\end{tabular}

The $\mathrm{Cu}$ content was significantly lower in exuviae than in larvae and adults in all the studied areas. The $\mathrm{Pb}$ and $\mathrm{Sr}$ contents showed high variability among the studied areas. The lowest $\mathrm{Pb}$ content was found in the exuviae in Balsa, while in case of the other studied areas the Pb content was similar in the different developmental stages. The Sr content was significantly higher in larvae than in exuviae and adults in Balsa (Table 3). 
Table 3. Trace element contents per individual (expressed as mean $\pm \mathrm{SE}$, unit: $\mu \mathrm{g}$ ) of G. flavipes developmental stages in the Balsa studied area. Notations: different letters indicate the significant differences at $p<0.05$.

\begin{tabular}{cccc}
\hline \multirow{2}{*}{ Elements } & \multicolumn{3}{c}{ Stages } \\
\cline { 2 - 4 } & Larvae & Exuviae & Adults \\
\hline $\mathrm{Al}$ & $41.3 \pm 2.1^{\mathrm{a}}$ & $113.7 \pm 3.7^{\mathrm{b}}$ & $3.6 \pm 0.1^{\mathrm{c}}$ \\
$\mathrm{Ba}$ & $2.3 \pm 0.2^{\mathrm{a}}$ & $1.9 \pm 0.1^{\mathrm{a}}$ & $0.1 \pm 0.01^{\mathrm{b}}$ \\
$\mathrm{Cr}$ & $0.1 \pm 0.01^{\mathrm{a}}$ & $0.3 \pm 0.01^{\mathrm{b}}$ & $0.01 \pm 0.01^{\mathrm{a}}$ \\
$\mathrm{Cu}$ & $17.8 \pm 1.5^{\mathrm{a}}$ & $0.6 \pm 0.02^{\mathrm{b}}$ & $121.9 \pm 19.4^{\mathrm{a}}$ \\
$\mathrm{Fe}$ & $61.2 \pm 3.1^{\mathrm{a}}$ & $163.0 \pm 5.5^{\mathrm{b}}$ & $7.7 \pm 0.7^{\mathrm{c}}$ \\
$\mathrm{Mn}$ & $5.3 \pm 0.4^{\mathrm{a}}$ & $13.2 \pm 0.8^{\mathrm{b}}$ & $0.4 \pm 0.03^{\mathrm{c}}$ \\
$\mathrm{Pb}$ & $1.6 \pm 0.03^{\mathrm{a}}$ & $0.7 \pm 0.02^{\mathrm{b}}$ & $1.0 \pm 0.1^{\mathrm{c}}$ \\
$\mathrm{Sr}$ & $1.1 \pm 0.1^{\mathrm{a}}$ & $0.2 \pm 0.01^{\mathrm{b}}$ & $0.6 \pm 0.1^{\mathrm{c}}$ \\
$\mathrm{Zn}$ & $9.5 \pm 0.4^{\mathrm{a}}$ & $7.5 \pm 0.4^{\mathrm{b}}$ & $6.7 \pm 0.6^{\mathrm{b}}$ \\
\hline
\end{tabular}

In Tuzsér (Table 1) and in Tiszafüred (Table 4), the Sr content was the highest in exuviae, while significant differences were not found among the developmental stages in Tiszabercel (Table 2). In all studied areas we found a positive correlation between the trace element content of larvae and the sum of the trace element content of exuviae and adult (Figure 2).

Table 4. Trace element contents per individual (expressed as mean \pm standard error, unit: $\mu \mathrm{g}$ ) of $G$. flavipes developmental stages in the Tiszafüred studied area. Notations: different letters indicate the significant differences at $p<0.05$.

\begin{tabular}{cccc}
\hline \multirow{2}{*}{ Elements } & \multicolumn{3}{c}{ Stages } \\
\cline { 2 - 4 } & Larvae & Exuviae & Adults \\
\hline $\mathrm{Al}$ & $23.2 \pm 1.6^{\mathrm{a}}$ & $87.7 \pm 3.5^{\mathrm{b}}$ & $1.0 \pm 0.1^{\mathrm{c}}$ \\
$\mathrm{Ba}$ & $1.1 \pm 0.1^{\mathrm{a}}$ & $2.1 \pm 0.1^{\mathrm{b}}$ & $0.1 \pm 0.04^{\mathrm{c}}$ \\
$\mathrm{Cr}$ & $0.04 \pm 0.01^{\mathrm{a}}$ & $0.2 \pm 0.01^{\mathrm{b}}$ & $0.01 \pm 0.01^{\mathrm{c}}$ \\
$\mathrm{Cu}$ & $3.0 \pm 0.2^{\mathrm{a}}$ & $0.9 \pm 0.03^{\mathrm{b}}$ & $3.7 \pm 0.2^{\mathrm{a}}$ \\
$\mathrm{Fe}$ & $99.5 \pm 7.8^{\mathrm{a}}$ & $227.5 \pm 11.2^{\mathrm{b}}$ & $8.5 \pm 0.3^{\mathrm{c}}$ \\
$\mathrm{Mn}$ & $6.7 \pm 0.5^{\mathrm{a}}$ & $11.2 \pm 0.7^{\mathrm{b}}$ & $0.3 \pm 0.01^{\mathrm{c}}$ \\
$\mathrm{Pb}$ & $0.2 \pm 0.02^{\mathrm{a}}$ & $0.3 \pm 0.02^{\mathrm{b}}$ & $0.02 \pm 0.01^{\mathrm{c}}$ \\
$\mathrm{Sr}$ & $0.7 \pm 0.02^{\mathrm{a}}$ & $0.9 \pm 0.02^{\mathrm{b}}$ & $0.4 \pm 0.01^{\mathrm{c}}$ \\
$\mathrm{Zn}$ & $15.5 \pm 0.7^{\mathrm{a}}$ & $7.6 \pm 0.5^{\mathrm{b}}$ & $11.1 \pm 0.2^{\mathrm{c}}$ \\
\hline
\end{tabular}



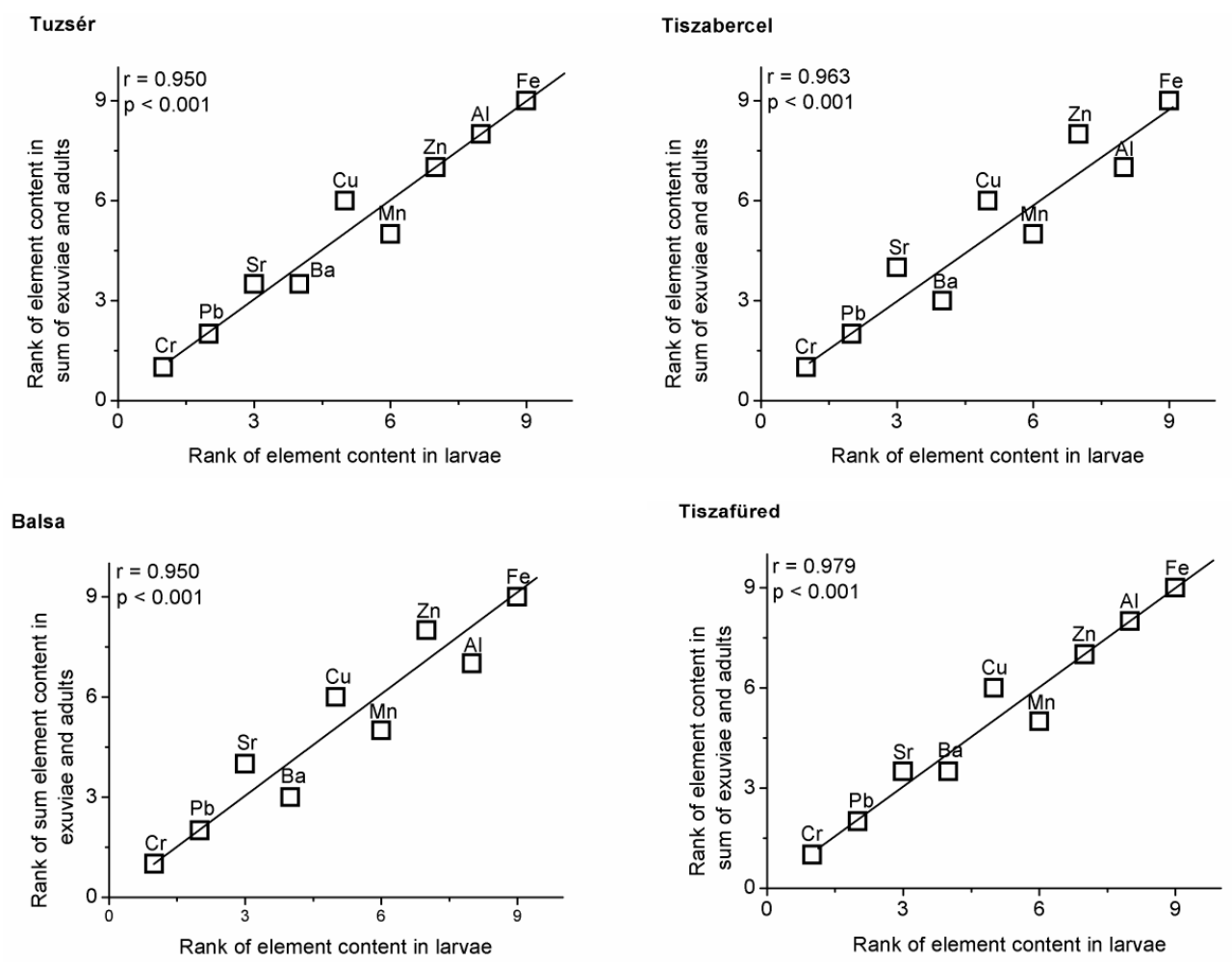

Figure 2. Pearson's rank correlation between trace element content of larvae (element per individual, unit: $\mu \mathrm{g}$ ) and the sum of the trace element content (element per individual, unit: $\mu \mathrm{g}$ ) in exuviae and adults.

\section{Discussion}

In our study, the trace element concentrations of larvae, exuviae and adults were analysed in a dragonfly species $G$. flavipes. Our study demonstrated that all stages-arvae, exuviae and adults were useful to detect metal bioavailability. The decontamination process under conditions of the intensive intake of trace elements is the production of excrement. Moulting and thus the exoskeletonis a detoxification method for eliminating the soft tissue burdens of metals; similar findings were reported by Gupta [25] and Meyer et al. [29].

Trace elements can be adsorbed and/or associated on the surface of the exoskeleton and the last moulting may be a way for arthropods to depurate metals. Among the trace elements studied, $\mathrm{Zn}$, $\mathrm{Mn}$ and $\mathrm{Fe}$ are essential for insects because the different parts of the cuticle also may contain high concentrations of $\mathrm{Zn}, \mathrm{Fe}$ and $\mathrm{Mn}$ [41]. In the case of insects, Ba and Sr occur most frequently in the malpighian tubules, less often in the midgut and reproductive organs, and very occasionally in the hindgut and fat body. Both elements may be absorbed in the midgut of most insects [42]. Cr is also an essential micronutrient for the normal energy metabolism of humans and animals, and $\mathrm{Cr}$ can control the metabolism of glucose and lipids [43]. Sub-lethal effects of copper may occur in the developmental and reproductive biology of insects [44]. However, $\mathrm{Cu}$ is essential for the growth and development of aquatic species [43]. The toxicity of $\mathrm{Al}$ is remarkable to aquatic animals in acidic waters, especially in lakes and rivers. High concentrations of Al may cause increasing or decreasing levels of locomotor activity in insects [45].

The terminal moult can reduce the burdens of trace elements on the body [46,47]. The mechanism of contaminant losses includes the exuviae, which is shed by final larval or newly emerged adults. We demonstrated that moulting has a detoxification role because we found significantly higher $\mathrm{Al}, \mathrm{Fe}$ and Mn contents in exuviae than in larvae and adults. Kraus et al. [30] demonstrated that some trace elements were lost during metamorphosis, leading to 2- to 125-fold higher larval concentrations and a higher exposure risk for predators of larvae compared to for predators of adults. Kraus et al. [30] 
also reported that $\mathrm{Zn}, \mathrm{Cd}$ and $\mathrm{Cu}$ are lost during the metamorphosis. In contrast, the $\mathrm{Cu}$ and Zn concentrations were similar in larvae and adults in our study, except for the studied locality of Balsa, where the highest $\mathrm{Cu}$ concentration was found in adults. In Balsa, the high $\mathrm{Cu}$ and $\mathrm{Zn}$ concentrations were caused by the main canal, the Lónyai-fócsatorna, which is contaminated by communal wastewater [36]. Lavilla et al. [48] demonstrated that $\mathrm{Cu}$ and $\mathrm{Zn}$ were associated with the inner parts of dragonfly larvae, while an efficient excretory mechanism was found for $\mathrm{Cu}$ between larval and subimaginal stages in mayflies. Keteles and Fleeger [27] also reported that $\mathrm{Cu}$ can be reabsorbed before moulting. Thus, metals also can be absorbed and accumulated in the gut [49]. Hare et al. [50] reported that trace elements were not uniformly distributed along the gut and the trace element distribution mainly depended on trace element and insect species. Mogren et al. [51] reported that Chironomus riparius can eliminate $72 \%$ of the As burden in the body before reaching the adult stage. Similar findings were reported by Timmermans and Walkers [52] when Stictochironomus histrio was studied, and they found that the level of trace metals increased in the pupal skin. Muscatello and Liber [53] also demonstrated that the exuviae play an important role in detoxification; they found that $\mathrm{U}$ losses of the pupal skin during metamorphosis accounted for $22 \%$ to $58 \%$ of the U accumulated in Chironomus tentans.

Earlier studies demonstrated that metals were adsorbed in the exoskeleton and the concentration of the trace elements decreases during metamorphosis at high larvae exposure levels [30,54]. Mogren et al. [51] reported that concentrations of trace elements were not detected in exuviae because the sample mass was very small. During metamorphosis, insects lose their mass, while the decline in concentrations of trace elements can lead to a loss in burden, as excretion of contaminant mass occurs [54]. Many scientists have identified the tendency of insect immature stages to eliminate a negatively acting trace element through their gut, and the greater part is excluded in the frass material. Production of excrement is better at this elimination because it is a continual process, and the change of instar or more precisely the creation of exuviae is strictly segmental [27,30]. Moreover, the process of trace element elimination is absolutely independent of ecdysis in the case of adult specimens [27]. We found a strong correlation between the trace element content of larvae and the aggregate trace element content of exuviae. At the same time, the higher concentrations of some elements in the cuticle of insects are related to the natural hardening of body structure after the process of ecdysis. Our findings indicate that remarkable weight changes cause the differences among developmental stages. Similar to earlier studies, we found that the developmental stages of Odonata are useful indicators of environmental health [55-57]. The exuviae are a significant stage of metals removal; exuviae are also useful to assess the environmental health of an aquatic ecosystem based on the exuviae of protected dragonfly species. Hardersen et al [58] and Gladysz et al. [54] also reported that the exuviae stage of dragonfly may be a useful stage during which water quality is assessed. Luoma and Carter [59] demonstrated that varying sensitivity to environmental factors among individuals is a common genetically driven characteristic of an aquatic invertebrate population. Our results also demonstrated that the analysis of exuviae of $G$. flavipes represents a new opportunity for studying the variability of elemental contents or their effects on insects in environmental studies.

\section{Conclusions}

We emphasise that dragonflies are useful indicators for assessing the quality of both terrestrial and aquatic ecosystems. Our findings suggest that exuviae are especially useful in environmental assessment because it is easy to collect them, and sample collection is cost-effective. Moreover, this method may be used with protected species, because there is no need to avoid euthanising specimens of these species. Thus, the analysis of exuviae of G. flavipes is a new opportunity for studying the variability of trace element contents of dragonfly and damselfly populations. The study of exuviae facilitates more detailed environmental investigations and even the historical analysis of aquatic ecosystems based on existing collections of exuviae [28]. 
Supplementary Materials: The following are available online at http://www.mdpi.com/2073-4441/11/11/2200/s1, Table S1: Canonical discriminant analysis of element content per individual of different stages of G. flavipes in the Balsa studied area, Table S2: Canonical discriminant analysis of element content per individual of different stages of G. flavipes in the Tiszabercel studied area, Table S3: Canonical discriminant analysis of element content per individual of different stages of G. flavipes in the Tiszafüred studied area, Table S4: Canonical discriminant analysis of element content per individual of different stages of G. flavipes in the Tuzsér studied area, Table S5: Results of non-parametric Kruskal-Wallis H test based on the element content per individual of different stages of G. flavipes.

Author Contributions: Sample collection, O.K., P.É.S., T.J. and A.V.; sample preparation and elemental analysis, O.K., M.M., E.B. and S.H.; data analysis and writing of review and editing, E.S., G.D. and B.T.

Funding: Research was supported by OTKA K 116639, KH 126481 and KH 126477 projects. It was also supported by the EU and co-financed by the European Social Fund under the ENVIKUT Project (TÁMOP-4.2.2. A-11/1/KONV-2012-0043) and the Internal Research Project of the University of Debrecen (E. Simon). O.K. and P.E.S. were supported by the European Union and the State of Hungary, co-financed by the European Social Fund in the framework of the TÁMOP 4.2.4. A/2-11-1-2012-0001 "National Excellence Program".

Conflicts of Interest: The authors declare no conflicts of interest.

\section{References}

1. Islam, S.; Ahemd, K.; Raknuzzaman, M.; Al Mamun, H.; Islam, M.K. Heavy metal pollution in surface water and sediment: A preliminary assessment of an urban river in a developing country. Ecol. Indic. 2015, 48, 282-291. [CrossRef]

2. Varol, M.; Sen, B. Assessment of nutrient and heavy metal contamination in surface water and sediments of the Upper Tigris River, Turkey. Catena 2012, 92, 1-10. [CrossRef]

3. Merly, L.; Lange, L.; Meyer, M.; Hewitt, A.M.; Koen, P.; Fischer, C.; Muller, J.; Schilack, V.; Wentzel, M.; Hammerschlag, N. Blood plasma levels of heavy metals and trace elements in white sharks (Carcharodon carcharias) and potential health consequences. Mar. Pollut. Bull. 2019, 142, 85-92. [CrossRef] [PubMed]

4. D’Errico, G.; Vitiello, G.; De Tommaso, G.; Abdel-Gawad, F.K.; Brundo, M.V.; Ferrante, M.; De Maio, A.; Trocchia, S.; Bianchi, A.R.; Ciarcia, G.; et al. Electron Spin Resonance (ESR) for the study of Reactive Oxygen Species (ROS) on the isolated frog skin (Pelophylax bergeri): A non-invasive method for environmental monitoring. Environ. Res. 2018, 165, 11-18. [CrossRef] [PubMed]

5. Guerriero, G.; Di Giaimo, R.; Hentati, O.; Abdel-Gawad, F.K.; Trocchia, S.; Rabbito, D.; Ciarcia, G. Reproductive expression dynamics and comparative toxicological perspective of beta estrogen receptor gene in the male wall lizard, Podarcissicula Rafinesque, 1810 (Chordata: Reptilia). Eur. Zool. J. 2018, 85, 332-342. [CrossRef]

6. Luo, J.; Li, X.; Wang, Y.; Li, H. Characterization of $\mathrm{Pb}$ and Cd contamination in the feces and feathers of rook (Corvus frugilegus) and the scalp hair of residents in Qiqihar, northeastern China. Hum. Ecol. Risk Assess. 2018, 24, 494-508. [CrossRef]

7. Grúz, A.; Mackle, O.; Bartha, A.; Szabó, R.; Déri, J.; Budai, P.; Lehel, J. Biomonitoring of toxic metals in feathers of predatory birds from eastern regions of Hungary. Environ. Sci. Pollut. Res. 2019, 26, 26324-26331. [CrossRef]

8. Currie, R.S.; Fairchild, W.L.; Muir, D.C.G. Remobilization and export of cadmium from lake sediments by emerging insects. Environ. Toxicol. Chem. 1997, 16, 2333-2338. [CrossRef]

9. Walters, D.M.; Fritz, K.M.; Otter, R.R. The dark side of subsidies: Adult stream insects export organic contaminants to riparian predators. Ecol. Appl. 2008, 18, 1835-1841. [CrossRef]

10. Wilbur, H.M. Complex life cycles. Annu. Rev. Ecol. Syst. 1980, 11, 67-93. [CrossRef]

11. Polis, G.A.; Anderson, W.B.; Holt, R.D. Toward and integration of landscape and food web ecology: The dynamics of spatially subsidized food webs. Annu. Rev. Ecol. Syst. 1997, 28, 289-316. [CrossRef]

12. Baxter, C.V.; Fausch, K.D.; Saunders, W.C. Tangled webs: Reciprocal flows of invertebrate prey link streams and riparian zones. Freshw. Biol. 2005, 50, 201-220. [CrossRef]

13. Oertli, B. The use of dragonflies in the assessment and monitoring of aquatic habitats. In Dragonflies and Damselflies: Model Organisms for Ecological and Evolutionary Research; Córdoba-Aguilar, A., Ed.; Oxford University Press: Oxford, NY, USA, 2008; pp. 79-96.

14. Blackwell, B.D.; Drenner, R.W. Mercury contamination of macroinvertebrates in fishless grassland ponds. Southwest. Nat. 2009, 54, 468-474. [CrossRef]

15. Tollet, V.D.; Benvenutti, E.L.; Deer, L.A.; Rice, T.M. Differential toxicity of $\mathrm{Cd}, \mathrm{Pb}$, and $\mathrm{Cu}$ in dragonfly larvae (Insecta: Odonata). Arch. Environ. Contam. Toxicol. 2009, 56, 77-84. [CrossRef] [PubMed] 
16. Haro, R.J.; Bailey, S.W.; Northwick, R.M.; Rolfhus, K.R.; Sandheinrich, M.B.; Wiener, J.G. Burrowing dragonfly larvae as biosentinels of methylmercury in freshwater food webs. Environ. Sci. Technol. 2013, 47, 8148-8156. [CrossRef]

17. Haro, R.J. All along the watchtower: Larval dragonflies are promising biological sentinels for monitoring methylmercury contamination. Park Sci. 2014, 31, 70-73.

18. Pryke, J.S.; Sammays, M.J.; De Saedleer, K. An ecological network is as good as a major protected area for conserving dragonflies. Biol. Conserv. 2015, 191, 537-545. [CrossRef]

19. Nehring, R.B.; Nisson, R.; Minasian, G. Reliability of aquatic insects versus water samples as measures of aquatic lead pollution. Bull. Environ. Contam. Toxicol. 1979, 22, 103-108. [CrossRef]

20. Yevtushenko, N.Y.; Bren, N.V.; Sytnik, Y.M. Heavy metal contents in invertebrates of the Danube river. Water Sci. Technol. 1990, 22, 119-125. [CrossRef]

21. Buckland-Nicks, A.; Hillier, K.N.; Avery, T.S.; O'Driscoll, N.J. Mercury bioaccumulation in dragonflies (Odonata: Anisoptera): Examination of life stages and body regions. Environ. Toxicol. 2014, 33, 2047-2054. [CrossRef]

22. Nasirian, H.; Irvine, K.N. Odonata larvae as a bioindicator of metal contamination in aquatic environments: Application to ecologically important wetlands in Iran. Environ. Monit. Assess. 2017, 189, 436. [CrossRef] [PubMed]

23. Corbi, J.J.; Froehlich, C.G. Bioaccumulation of metals in aquatic insects of streams located in area with sugar cane cultivation. Quim. Nova 2010,33, 644-648. [CrossRef]

24. Cid, N.; Ibánez, C.; Palanques, A.; Prat, N. Patterns of metal bioaccumulation in two filter-feeding macroinvertebrates: Exposure distribution, inter-species differences and variability across developmental stages. Sci. Total Environ. 2010, 408, 2795-2806. [CrossRef] [PubMed]

25. Gupta, A. Metal accumulation and loss by Crocothemis servilla (Drury) in a small lake in Shillong, Northeastern India (Anisoptera: Libellulidae). Odonatologica 1995, 24, 283-289.

26. Khan, F.R.; Bury, N.R.; Hogstrand, C. Copper and zinc detoxification in Gammarus pulex (L.). J. Exp. Biol. 2012, 215, 822-832. [CrossRef] [PubMed]

27. Keteles, K.A.; Fleeger, J.W. The contribution of ecdysis to the fate of copper, zinc and cadmium in Grass Shrimp, Palaemonetes pugio Holthius. Mar. Pollut. Bull. 2001, 42, 1397-1402. [CrossRef]

28. Bergey, L.L.; Weis, J.S. Molting as a mechanism of depuration of metals in the fiddler crab, Uca pugnax. Mar. Environ. Res. 2007, 64, 556-562. [CrossRef]

29. Meyer, W.; Harisch, G.; Sagredos, A.N. Biocehmical and histochemical aspects of lead exposure in dragonfly larvae (Odonata: Anisoptera). Ecotox. Environ. Safe 1986, 11, 308-319. [CrossRef]

30. Kraus, J.M.; Walters, D.M.; Wesner, J.S.; Stricker, C.A.; Schmidt, T.S.; Zuelling, R.E. Metamorphosis alters contaminants and chemical tracers in insects: Implications for food webs. Environ. Sci. Technol. 2014, 48, 10957-10965. [CrossRef]

31. Bulánková, E.; Beracko, P.; Derka, T. Occurrence of Protected Species (Gomphus flavipes, Odonata and Palingenia longicauda, Ephemeroptera) in the Danube River and its Deltas (Romania, Slovakia). Sci. Ann. Danube Delta Inst. 2013, 19, 21-24.

32. Kazanci, N.; Dügel, M. Determination of influence of heavy metals on structure of benthic macroinvertebrate assemblages in low order Mediterranean streams by using canonical correspondence analysis. Rev. Hydrobiol. 2010, 3, 13-26.

33. Boudot, J.P.; Kalkman, V.J. (Eds.) Atlas of the European Dragonflies and Damselflies; KNNV Publishing: Zeist, The Netherlands, 2015; p. 381.

34. Suhling, F.; Müller, O. Die Flußjungfern Europas-Gomphidae. In Die Neue Brehm-Bücherei 628.-Westarp Wissenschaften, Magdeburg \& Spektrum Akademischer; Springer: Heidelberg, Germany, 1996; p. 237.

35. Jakab, T.; Dévai, G. A folyami szitakötők (Odonata: Gomphidae) előfordulása Magyarországon a lárva-és exuviumadatok alapján. [The occurrence of the riverine dragonfly-species (Odonata: Gomphidae) in Hungary according to data of larvae and exuviae]. Acta Biol. Debrecina Suppl. Oecol. Hung 2008, 18, $53-65$.

36. Simon, E.; Kis, O.; Jakab, T.; Kolozsvári, I.; Málnás, K.; Harangi, S.; Baranyai, E.; Miskolczi, M.; Tóthmérész, B.; Dévai, G. Assessment of contamination based on trace element concentration of dragonfly larvae in the Upper Tisza Region. Ecotox. Environ. Safe 2017, 136, 55-61. [CrossRef] [PubMed]

37. Braun, M.; Simon, E.; Fábian, I.; Tóthmérész, B. The effects of ethylene glycol and ethanol on the body mass and elemental composition of insects collected with pitfall traps. Chemosphere 2009, 77, 1447-1452. [CrossRef] [PubMed] 
38. Braun, M.; Simon, E.; Fábián, I.; Tóthmérész, B. Elemental analysis of pitfall-trapped insect samples: Effects of ethylene glycol grades. Entomol. Exp. Appl. 2012, 143, 89-94. [CrossRef]

39. Simon, E.; Harangi, S.; Baranyai, E.; Braun, M.; Fábián, I.; Mizser, S.; Nagy, L.; Tóthmérész, B. Distribution of toxic elements between biotic and abiotic components of terrestrial ecosystem along an urbanization gradient: Soil, leaf litter and ground beetles. Ecol. Indic. 2016, 60, 258-264. [CrossRef]

40. Landau, S.; Everitt, B.S. A Handbook of Statistical Analysis Using SPSS; Chapman and Hall: London, UK, 2003.

41. Zhuang, P.; Zou, H.; Shu, W. Biotransfer of heavy metals along a soil-plant-insect-chicken food chain: Field study. J. Environ. Sci. 2009, 21, 849-853. [CrossRef]

42. Waterhouse, D.F. The occurence of barium and strontium in Insects. Aust. J. Biol. Sci. 1951, 4, $144-162$. [CrossRef]

43. Kabata-Pendias, A.; Pendias, H. Trace Elements in Soils and Plants, 3rd ed.; CRC Press: Boca Raton, FL, USA, 2001.

44. Michaud, J.P.; Grant Angela, K. Sub-lethal effects of a copper sulfate fungicide on development and reproduction in three coccinellid species. J. Insect Sci. 2003, 3, 16.

45. Kijak, E.; Rosato, E.; Knapczyk, K.; Pyza, E. Drosophila melanogaster as a model system of aluminum toxicity and aging. Insect Sci. 2014, 21, 189-202. [CrossRef]

46. Reichmuth, J.M.; Weis, P.; Weis, J.S. Bioaccumulation and depuration of metals in blue crabs (Callinectes sapidus Rathbun) from a contaminated and clean estuary. Environ. Pollut 2010, 158, 361-368. [CrossRef] [PubMed]

47. Metian, M.; Hédouin, L.; Eltayeb, M.; Lacoue-Labarthe, T.; Teyssié, J.L.; Mugnier, C.; Bustamante, P.; Warnau, M. Metal and metalloid bioaccumulation in the Pacific blue shrimp Litopenaeus stylirostis (Stimpson) from New Caledonia: Laboratory and field studies. Mar. Pollut. Bull. 2010, 61, 576-584. [CrossRef] [PubMed]

48. Lavilla, I.; Rodriguez-Linares, G.; Garrido, J.; Bendicho, C. A biogeochemical approach to understanding the accumulation patterns of trace elements in three species of dragonfly larvae: Evaluation as biomonitors. J. Environ. Monit. 2010, 12, 724-730. [CrossRef] [PubMed]

49. Smock, L.A. Relationships between metal concentrations and organism size in aquatic insects. Freshw. Biol. 1983, 13, 313-321. [CrossRef]

50. Hare, L.; Tessier, A.; Campbell, P.G.C. Trace element distributions in aquatic insects: Variations among genera, elements and lakes. Can. J. Fish. Aquat. Sci. 1991, 48, 1481-1491. [CrossRef]

51. Mogren, C.L.; von Kiparski, G.R.; Parker, D.R.; Trumble, J.T. Survival, reproduction and arsenic body burdens in Chironomus riaprius exposed to arsenate and phosphate. Sci. Total Environ. 2012, 425, 60-65. [CrossRef]

52. Timmermans, K.R.; Walker, P.A. The fate of trace metals during the metamorphosis of Chironomids (Diptera, Chironomidae). Environ. Pollut. 1989, 632, 73-85. [CrossRef]

53. Muscatello, J.R.; Liber, K. Accumulation and chronic toxicity of uranium over different life stages of the aquatic invertebrate Chironomus tentans. Arch. Environ. Contam. Toxicol. 2009, 57, 531-539. [CrossRef]

54. Gladysz, M.; Dolezych, B.; Cuber, P.; Karcz, J.; Laszczyca, P.; Miszta, A. Mud sediments on anal pyramids of Libellula quadrimaculata larvae-accidental phenomenon or bioindicator of heavy metal pollution? (Odonata: Libellulidae). Odonatologica 2016, 45, 179-189.

55. Clausnitzer, V.; Kalkman, V.J.; Ram, M.; Collen, B.; Baillie, J.E.M.; Bedja, M.; Darwall, W.R.T.; Dijkstra, K.D.B.; Dow, R.; Hawking, J.; et al. Odonata enter the biodiversity crisis debate: The first global assessment of an insect group. Biol. Conserv. 2009, 142, 1864-1869. [CrossRef]

56. Raebel, E.M.; Merckx, T.; Riordan, P.; Macdonald, D.W.; Thompson, D.J. The dragonfly delusion: Why it is essential to sample exuvial to avoid biased surveys. J. Insect. Conserv. 2010, 14, 523-533. [CrossRef]

57. Córdoba-Aguilar, A. (Ed.) Dragonflies and Damselflies: Model. In Organisms for Ecological and Evolutionary Research; Oxford University Press: Oxford, NY, USA, 2008; pp. 79-96.

58. Hardersen, S.; Corezzola, S.; Gheza, G.; Dell'Otto, A.; La Porta, G. Sampling and comparing odonate assemblages by means of exuviae: Statistical and methodological aspects. J. Insect Conserv. 2017. [CrossRef]

59. Luoma, S.N.; Carter, J.L. Effects of trace metals on aquatic benthos. In Metal Ecotoxicology Concepts and Applications; Newman, M.C., McInthos, A.W., Eds.; Lewis Publishers: Chelsea, MI, USA, 1991.

(C) 2019 by the authors. Licensee MDPI, Basel, Switzerland. This article is an open access article distributed under the terms and conditions of the Creative Commons Attribution (CC BY) license (http://creativecommons.org/licenses/by/4.0/). 